\title{
Bilateral septic arthritis of the shoulder: case report and literature review
}

Artrite séptica bilateral do ombro: relato de caso e revisão da literature

Artritis séptica bilateral del hombro: reporte de un caso y revisión de la literature

Roberto Barreto MAIA ${ }^{1}$

Lucas Fraga Cunha da SILVA ${ }^{1}$

Herbert Nascimento dos SANTOS ${ }^{\mathbf{1}}$

Fernando Antônio Batista ANDRADE ${ }^{1}$

Marcos Antônio Almeida MATOS ${ }^{1}$

Rogério Meira BARROS ${ }^{1}$

Marcus Vinícius Silva SANTOS ${ }^{1}$

Luis Guilherme Rosifini Alves REZENDE ${ }^{2}$

${ }^{1}$ Department of Orthopedics and Traumatology, Santa Casa de Misericórdia da Bahia - Hospital Santa Izabel, 40050-410 Salvador, Bahia, Brazil

${ }^{2}$ Hand and Upper Limb Surgeon, Hospital das Clínicas da Faculdade de Medicina de Ribeirão Preto da Universidade de São Paulo (HC-FMRP-USP) 14015-010 Ribeirão Preto - SP, Brazil

\begin{abstract}
Bilateral shoulder septic arthritis is a rare condition in immunocompetent patients without known risk factors, therefore, it can be easily misdiagnosed. Septic arthritis is an emergency due to its potential to cause rapid destruction of cartilage and bone as well as the risk for systemic spread. Aggressive early treatment is crucial for easing pain, preventing joint collapse, and permanent loss of shoulder function. We presented a case report of a 68 years-old man, suffering from multiple comorbidities and bilateral shoulder septic arthritis. The patient underwent arthroscopic surgery in the left shoulder. Antibiotic therapy was carried out after the surgical procedure using clindamycin. The patient had a satisfactory outcome, characterized by regression of the inflammatory symptoms in both shoulders. There was an improvement in pain and fevers settled. In this case report, we have also discussed treatment options as well as possible outcomes.
\end{abstract}

Descriptors: Arthritis, Infectious; Shoulder; Sepsis.

\section{Resumo}

A artrite séptica bilateral do ombro é uma condição rara em pacientes imunocompetentes sem fatores de risco conhecidos, portanto, podendo ser facilmente subdiagnosticada. A artrite séptica é uma emergência devido ao seu potencial de causar rápida destruição da cartilagem e do osso, além do risco de disseminação sistêmica. O tratamento precoce agressivo é crucial para aliviar a dor, prevenir o colapso das articulações e a perda permanente da função do ombro. Apresentamos o relato de caso de um homem de 68 anos com múltiplas comorbidades e artrite séptica bilateral do ombro. O paciente foi submetido a cirurgia artroscópica em ombro esquerdo. A antibioticoterapia foi realizada após o procedimento cirúrgico com clindamicina. 0 paciente evoluiu de forma satisfatória, caracterizada por regressão dos sintomas inflamatórios em ambos os ombros. Houve melhora da dor e melhora das febres. Neste relato de caso, também discutimos as opções de tratamento, bem como os resultados possíveis.

Descritores: Artrite Infecciosa; Ombro; Sepse.

\section{Resumen}

La artritis séptica bilateral del hombro es una enfermedad poco común en pacientes inmunocompetentes sin factores de riesgo conocidos, por lo que puede diagnosticarse erróneamente con facilidad. La artritis séptica es una emergencia debido a su potencial para causar una rápida destrucción de cartílago y hueso, así como el riesgo de diseminación sistémica. El tratamiento temprano agresivo es crucial para aliviar el dolor, prevenir el colapso articular y la pérdida permanente de la función del hombro. Presentamos un caso clínico de un varón de 68 años, con múltiples comorbilidades y artritis séptica bilateral del hombro. El paciente fue sometido a cirugía artroscópica en el hombro izquierdo. Posterior al procedimiento quirúrgico se realizó antibioterapia con clindamicina. El paciente tuvo una evolución satisfactoria, caracterizada por la regresión de los síntomas inflamatorios en ambos hombros. Hubo una mejoría en el dolor y la fiebre se calmó. En este informe de caso, también hemos analizado las opciones de tratamiento, así como los posibles resultados.

Descriptores: Artritis Infecciosa; Hombro; Sepsis.

\section{INTRODUCTION}

Septic arthritis is an emergency due to its potential to cause rapid destruction of cartilage and bone as well as the risk for systemic spread $^{1,2}$. The most common affected sites are hip and knee, which account for approximately 61 to $79 \%$ of cases; the shoulder is the third most affected site representing about 3 to $15 \%$ of the total number of sites ${ }^{2,5}$.

The most common cause of a septic shoulder joint is hematogenous bacterial dissemination. There could also be associated factors predisposing to this infection such as previous surgical procedures or joint injections ${ }^{3,6,7}$. According to some studies both Staphylococcus aureus and Staphylococcus epidermidis are the most prevalent causative organisms ${ }^{8-10}$.

The diagnosis of shoulder septic arthritis Has been associated with a poorer prognosis and frequent sequelae, including recurrent joint effusion with or without a fistula, subluxation, dislocation, and chronic osteomyelitis ${ }^{11}$. Previous studies have shown that early diagnosis and treatment are essential to avoid irreversible soft tissue and joint damage $8,10,12,13$. Shoulder infection should be considered in patients presenting pain and progressive stiffness associated with elevated inflammatory serum markers as well as pain unresponsive to short-term nonsteroidal anti-inflammatory drugs. The likelihood of infection is increased by a history of joint injection followed by worsening of the symptoms ${ }^{9}$.

Early management is necessary for pain relief, preventing joint collapse, and permanent loss of shoulder function ${ }^{3}$. Surgical treatment options are joint aspiration, arthrotomy, or arthroscopy for irrigation and collecting samples 
for culture and analysis. Empirical antibiotics while waiting for culture results should be given as early as possible to avoid local and systemic complications. As far as we could ascertain, bilateral shoulder infection was only described once in the current literature. Therefore, the objective of the present study is to present a case of bilateral shoulder septic arthritis along with a literature review of this rare and disastrous condition.

\section{CLINICAL CASE}

A 68 years-old male subject complaining of bilateral shoulder pain (worse on the left side), associated with marked functional limitation on both sides for 20 days. There was also a history of fevers of around $38^{\circ} \mathrm{C}$ for 15 days. Despite the clinical features, the patient did not seek medical attention up to that time. There was pain, swelling and other inflammatory signs such as warmth and functional impairment. There was limited range of motion at clinical evaluation and joint swelling in both shoulders. He also had other medical conditions, such as systemic arterial hypertension, coronary artery disease, and chronic kidney disease requiring dialysis after bilateral nephrectomy for renal carcinoma.

Standard shoulder radiographs were performed. The right shoulder didn't present degenerative changes, while the left shoulder demonstrated joint space widening and no degenerative signs. Blood tests revealed $\mathrm{H} / \mathrm{H}$ of $5.6 \mathrm{gm} / \mathrm{dl}$ and $17.8 \%$ and normal WBC count $(7,640 / \mathrm{ml})$ with $75 \%$ of the neutrophil relative increase and elevated inflammatory markers (ESR and RCP). A left shoulder joint puncture showed seropurulent fluid, suggesting an infectious process. MRI of the left shoulder showed an increased signal in the subacromial bursa and a large volume of fluid in the glenohumeral joint, seen as an intermediate signal in the T1 and T2 sequences (Figures 1 an $2)$. There was thickening of the soft tissue, bleeding inside the bursa, and swelling around the joint. We excluded overlapping disease with amyloid arthropathy or acute crystal deposition.

The management was performed in the operating room where a new aseptic puncture of the left shoulder was performed. Then, the patient underwent arthroscopic debridement of the shoulder with three portals (posterior, anterior, anterolateral). The irrigation and debridement with a shaver blade and radio ablation were performed. No cartilage damage was observed by direct inspection of the joint. The subacromial space was also debrided along with its bursa. Antibiotic therapy was performed after the surgical procedure with clindamycin.
The right shoulder was not approached at the same time due to hemodynamic instability, being the same procedure performed on the right shoulder in the following days.

The patient evolved with the relief of shoulder symptoms. Culture tests were positive for Morganella morganii sensitive to etarpenem, meropenem, clindamycin, ciprofloxacin and third generation cyclosporins. Infectious diseases prescribed ciprofloxacin and intravenous clindamycin for 2 weeks, and orally for another 4 weeks. The patient died due to hemodynamic instability during hospitalization.

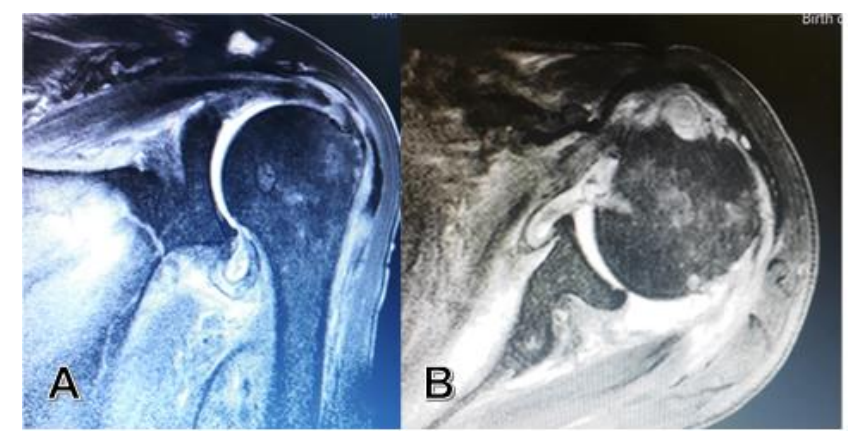

Figure 1: T2 MRI image of the left shoulder. A: Coronal. B: Axial

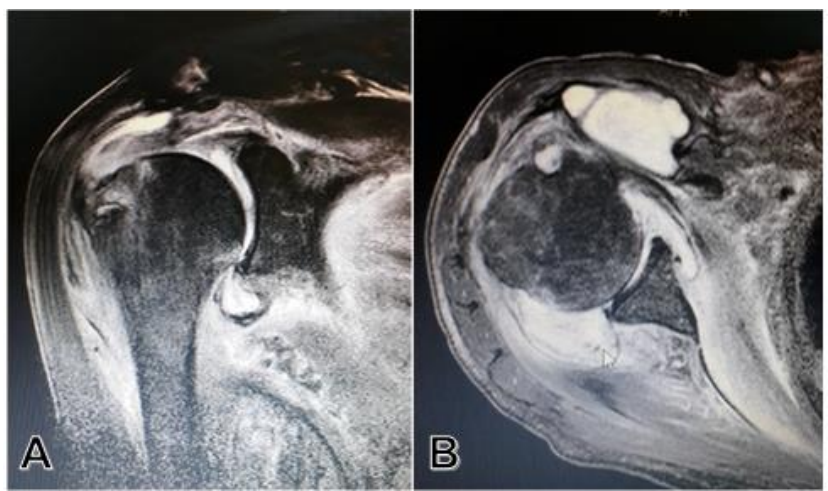

Figure 2: T2 MRI image of the right shoulder A: coronal. B: Axial

DISCUSSION

Septic arthritis is considered to be an orthopedic emergency. It is characterized by pyogenic inflammation of the articular surface due to bacterial invasion. The estimated overall prevalence of septic arthritis is 12 cases per 100.000 inhabitants per year. Around 3 to $21 \%$ of the cases affect the shoulder, which is the third most common site, and is most prevalent in patients over 60 years old ${ }^{2-5,8,10,14-17}$. Bilateral occurrence in the shoulder is exceedingly rare, and we have found only one case reported in the medical literature. The case published by Hotonu et al. described a 47-year-old previously healthy man without relevant risk factors for the presentation $^{18,19}$.

Signs and symptoms of septic arthritis consist of persistent joint pain without previous trauma, limited range of motion secondary to pain, edema, erythema, hypersensitivity, fever, and systemic signs of sepsis. Hotonu et al. ${ }^{18}$ in 
their retrospective review postulated that fever and joint stiffness were present in 40 and $21 \%$ of cases, respectively ${ }^{20}$. Laboratory findings may reveal high leukocyte count, increased erythrocyte sedimentation rate, and elevated levels of C-reactive protein. The joint aspirate may show purulent exudate and high leukocyte count, in addition to identifying the causative bacteria ${ }^{2}$.

Septic arthritis may be related to rheumatic diseases (rheumatoid arthritis, osteoarthritis, and other inflammatory arthritis), previous surgical procedures, diabetes, ulcers of the lower limbs, alcohol or intravenous drug abuse, injections of corticosteroids in the joints, and possibly HIV infection ${ }^{21,22}$. There was an association between septic arthritis and immunocompromise, the presence of comorbidities, and also previous joint disease $\mathrm{s}^{3,8,10,17,23-26}$. The most common form is by hematogenous dissemination. Staphylococcus aureus or Staphylococcus epidermidis are the most common germs in 42 to $77 \%$ of cases $^{2,3,8,10,13,14,17,20,23,27-30}$. Less aggressive bacteria are prevalent in hematogenous dissemination, while uncommon or resistant organisms are often seen in intravenous drug users and in immunocompromised patients ${ }^{31}$.

Morganella morganii is an optional gramnegative anaerobic bacterium related to the Enterobacteriaceae family found in the normal intestinal flora of humans. It causes urinary tract, abdominal and hepatobiliary infections. Advanced age, hospitalization, surgical procedures, use of antibiotics, and concomitant bacteremia were considered the most important risk factors for infections by $M$. morgani ${ }^{32}$. It is commonly associated with polyarticular septic arthritis, especially in healthy young patients, located mainly in the knee or ankle joints ${ }^{33}$.

Diagnostic imaging is a useful aid in therapeutic programming. Radiographic images may show joint degeneration, periosteal reaction, displacement of the humeral head and gases, and edema of the surrounding soft tissues. Most patients have abnormalities on the radiographic examination in the early stages of the disease ${ }^{34-36}$. Ultrasound is useful to detect intra-articular fluid and synovial hypertrophy, but it is limited in c ases of bone changes. MRI is a non-invasive and sensitive modality, capable of demonstrating intra-articular fluid, inflammation, bone marrow edema, damage to cartilage and bone erosion ${ }^{37}$. According to Lee et al. The identification of bone or cartilage changes by means of MRI can assist in guiding the most appropriate treatment method before the surgical procedure ${ }^{38}$.
Newman et al believe that the diagnosis of septic arthritis should be confirmed in the presence of a positive synovial fluid culture, or positive blood culture along with positive clinical signs even when the synovial fluid is negative; or purulent synovial fluid with negative culture due to previous use of antibiotics, but with positive clinical signs ${ }^{39}$. In some cases, the possibility of bacterial contamination of the collected material can be considered, especially when the clinical signs are not compatible, and the isolated bacterium is not likely. In these cases, it is recommended to monitor the patient through imaging tests and clinical evaluations without antibiotics ${ }^{40}$.

There are reports of success with nonoperative treatment, recommended only when surgery is not possible (elderly or clinical conditions) ${ }^{3,7,9,29,41}$. Gelberman et al. ${ }^{11}$ demonstrated worse results with conservative treatment in relation to surgery in terms of hospitalization and complications of septic arthritis, such as septicemia, shock, pneumonia, urinary tract infection, and death.

Surgical methods are joint aspiration, arthroscopy, or open debridement (arthrotomy), always associated with concomitant antibiotics ${ }^{1,10,12,13,17,27,28}$. Gordian et al. ${ }^{42}$ reported that arthroscopic treatment is effective in treating septic arthritis of the shoulder and also recommend a new approach to the persistence of symptoms. Open debridement is preferred in late diagnosis or in the final stages of infection, where the bone and cartilage destruction is already present ${ }^{43}$.

Arthroscopic debridement and irrigation have become the method of choice for the treatment of septic arthritis of the shoulder by many surgeons due to the simple approach of the joint, effective infection control, and shorter hospital stay ${ }^{41}$. Memon et al. $^{2}$ carried out a systematic review on the arthroscopic treatment of septic arthritis of the shoulder and concluded that this method results in pain relief, normalization of blood inflammatory markers and fevers, and enables a complete return to daily and sports activities. These authors emphasize the need for repeated procedures in $30 \%$ of patients. Joo et al. ${ }^{44}$ reported $87 \%$ of satisfactory results following arthroscopic debridement.

Lee et al. ${ }^{45}$ retrospectively evaluated patients after arthroscopic or open treatment. These authors observed a rate of reinfection in individuals without bone or cartilage lesions of $10 \%$ for arthroscopy and $15.4 \%$ for open debridement. In the presence of these lesions on radiography or MRI, patients submitted to the 
arthroscopic procedure had a rate of reinfection of $82 \%$, while the open procedure resulted in $18 \%$ (statistically significant difference).Other reports have shown that open debridement has led to considerable restriction of shoulder range of motion ${ }^{2,32}$.

The systematic review by Memon et al.2 did not demonstrate the superiority of arthroscopic or open treatment due to the lack of sufficient studies. Likewise, Bovonratwet et al. ${ }^{45}$ compared the two techniques and found no difference in terms of reoperations, surgical time, hospital stay, adverse events and need for readmission. According Böhler et al. ${ }^{46}$, after analyzing data of 59 consecutive patients which received arthroscopy or open arthrotomy, open arthrotomy is the more effective treatment method in septic arthritis of the shoulder.

Other reports have also shown that both approaches have similar results in the treatment of septic arthritis of the shoulder ${ }^{46}$.

FINAL CONSIDERATIONS

It is possible to conclude that septic arthritis of the shoulder can be managed effectively by means of surgical debridement when performed in conjunction with antibiotic therapy, and results in pain relief, improved range of motion, and return to daily and sports activities. The arthroscopic procedure has shown itself to be a promising alternative for many surgeons. However, it is important to assess the presence of bone or cartilaginous damage before considering arthroscopy. Concomitant bilateral septic arthritis of the shoulder is a rare occurrence, described only once in the literature and, in our report, the patient was effectively treated with arthroscopic debridement and antibiotic therapy.

\section{REFERENCES}

1. Jiang JJ, Piponov HI, Mass DP, Angeles JG, Shi LL. Septic arthritis of the shoulder: a comparison of treatment methods. J Am Acad Orthop Surg. 2017;25(8):e175-84.

2. Memon M, Kay J, Ginsberg L, de Sa D, Simunovic N, Samuelsson K et al. Arthroscopic management of septic arthritis of the native shoulder: a systematic review. Arthroscopy. 2018;34(2):625-46.e1.

3. Leslie BM, Harris JM 3rd, Driscoll D. Septic arthritis of the shoulder in adults. J Bone Joint Surg Am. 1989;71(10):1516-22.

4. Le Dantec L, Maury F, Flipo RM, Laskri S, Cortet B, Duquesnoy B, Delcambre B. Peripheral pyogenic arthritis. A study of one hundred seventy-nine cases. Rev Rhum Engl Ed. 1996;63(2):103-10.

5. Lossos IS, Yossepowitch O, Kandel L, Yardeni D, Arber N. Septic arthritis of the glenohumeral joint. A report of 11 cases and review of the literature. Medicine (Baltimore). 1998; 77(3):177-87.

6. Herrera MF, Bauer G, Reynolds F, Wilk RM, Bigliani LU, Levine WN. Infection after mini-open rotator cuff repair. J Shoulder Elb Surg. 2002;11(6):605-8.

7. Jerosch J. Akuter Gelenkinfekt. Diagnostik und Therapie [Acute joint infection--diagnosis and treatment]. Orthopade. 2004;33(11):1309-18; quiz 1319-20.

8. Klinger HM, Baums $\mathrm{MH}$, Freche $\mathrm{S}$, Nusselt $\mathrm{T}$, Spahn G, Steckel H. Septic arthritis of the shoulder joint: an analysis of management and outcome. Acta Orthop Belg. 2010;76(5):598-603.

9. Garofalo R, Flanagin B, Cesari E, Vinci E, Conti M, Castagna A. Destructive septic arthritis of shoulder in adults. Musculoskelet Surg. 2014;98(Suppl 1):35-9.

10. Abdel MP, Perry KI, Morrey ME, Steinmann SP, Sperling JW, Cass JR. Arthroscopic management of native shoulder septic arthritis. J Shoulder Elbow Surg. 2013;22(3):418-21.

11. Gelberman $\mathrm{RH}$, Menon J, Austerlitz MS, Weisman MH: Pyogenic arthritis of the shoulder in adults. J Bone Joint Surg Am 1980; 62(4):550-53.

12. Duncan SF, Sperling JW. Treatment of primary isolated shoulder sepsis in the adult patient. Clin Orthop Relat Res. 2008;466(6):1392-96.

13. Jeon $\mathrm{IH}$, Choi $\mathrm{CH}$, Seo JS, Seo KJ, Ko SH, Park JY. Arthroscopic management of septic arthritis of the shoulder joint. J Bone Joint Surg Am. 2006;88(8):1802-806.

14. Kennedy N, Chambers ST, Nolan I, Gallagher K, Werno A, Browne M et al. Native joint septic arthritis: epidemiology, clinical features, and microbiological causes in a New Zealand population. J Rheumatol. 2015;42(12):2392-97.

15. Weston VC, Jones AC, Bradbury N, Fawthrop $F$, Doherty M. Clinical features and outcome of septic arthritis in a single UK Health District 1982-1991. Ann Rheum Dis.1999;58(4):214-19.

16. Maneiro JR, Souto A, Cervantes EC, Mera A, Carmona L, Gomez-Reino JJ. Predictors of treatment failure and mortality in native septic arthritis. Clin Rheumatol. 2015;34(11):1961-67.

17. van den Ende KI, Steinmann SP. Arthroscopic treatment of septic arthritis of the elbow. J Shoulder Elbow Surg. 2012;21(8):1001-5.

18. Hotonu SA, Khan S, Jeavons R. Bilateral shoulder septic arthritis in a fit and well 47-yearold man. BMJ Case Rep. 2015; 2015: bcr2015211406.

19. Smith JW, Hasan MS. Infectious arthritis. In: Mandell GL, Bennett JE, Dolin R (eds). Principles and practice of infectious diseases. Philadelphia: Churchill Livingstone; 2000.p.1175-82.

20.Dubost JJ, Fis I, Denis P, Lopitaux R, Soubrier $\mathrm{M}$, Ristori JM et al. Polyarticular septic arthritis. 
Medicine (Baltimore). 1993;72(5):296-310.

21. Schlapbach P, Ambord C, Blöchlinger AM, Gerber NJ. Bacterial arthritis: are fever, rigors, leucocytosis and blood cultures of diagnostic value? Clin Rheumatol. 1990;9(1):69-72.

22. Gupta MN, Sturrock RD, Field M. A prospective 2-year study of 75 patients with adult-onset septic arthritis. Rheumatology. 2001;40(1): 24-30.

23. Mehta P, Schnall SB, Zalavras CG. Septic arthritis of the shoulder, elbow, and wrist. Clin Orthop Relat Res. 2006;451:42-5.

24. Assunção JH, Noffs GG, Malavolta EA, Gracitelli MEC, Lima ALM, Ferreira Neto AA. Septic arthritis of the shoulder and elbow: one decade of epidemiological analysis at a tertiary referral hospital. Rev bras ortop. 2018;53(6): 707-13.

25. Sanbandam NS, Atturu M. A case of septic arthritis of shoulder presenting as stiffness of the shoulder. J Orthop Case Rep. 2016;6(2):31-3.

26. Garner AJ, Sundram F, Harris K. Group C Neisseria meningitidis as a cause of septic arthritis in a native shoulder joint: a case report. Case Rep Orthop. 2011;2011:862487.

27. Moon JG, Biraris S, Bilaris S, Jeong WK, Kim $\mathrm{JH}$. Clinical resultsafter arthroscopic treatment for septic arthritis of the elbowjoint. Arthroscopy. 2014;30(6):673-78

28. Kirchhoff C, Braunstein V, Buhmann Kirchhoff S, Oedekoven T, Mutschler W, Biberthaler P. Stage-dependant management of septic arthritis of the shoulder in adults. Int Orthop. 2009;33(4):1015-24.

29. Hunter JG, Gross JM, Dahl JD, Amsdell SL, Gorczyca JT. Risk factors for failure of a single surgical debridement in adults with acute septic arthritis. J Bone Joint Surg Am. 2015; 97(7):558-64.

30. Gramlich Y, Klug A, Walter G, Kremer M, Hoffmann R, Kemmerer M. Septic Arthritis of Native Shoulder and Knee Joint: What Are the Differences in Bacterial Spectrum, Treatment, and Outcome? Surg Infect (Larchmt). 2020;21(4):391-97.

31.Pommering TL, Wroble RR. Septic arthritis of the shoulder: treating an atypical case. Phys Sportsmed. 1996;24(5):74-85.

32. Dessie SA, Dobariya V, Singh D, He P. A Case of Morganella morganii-induced Fetal Demise. Cureus. 2020;12(3):e7169.

33. Griffin PL, Griffin GD, Simon EL. Spontaneous septic arthritis in a patient without trauma, coinfection, or immunosuppression. Am J Emerg Med. 2013;31(11):1623.e3-4.

34. Burk DL Jr, Karasick D, Mitchell DG, Rifkin MD. MR imaging of the shoulder: correlation with plain radiography. AJR Am J Roentgenol. 1990;154(3):549-53.

35. Gompels BM, Darlington LG. Septic arthritis in rheumatoid disease causing bilateral shoulder dislocation: diagnosis and treatment assisted by grey scale ultrasonography. Ann Rheum Dis. 1981;40(6):609-11.

36. Resnik CS. Septic arthritis: a rare cause of drooping shoulder. Skeletal Radiol. 1992;21(5):307-9.

37. Sussmann AR, Cohen J, Nomikos GC, Schweitzer ME. Magnetic resonance imaging of shoulder arthropathies. Magn Reson Imaging Clin N Am 2012;20(2):349-71.

38. Lee DK, Rhee SM, Jeong HY, Ro K, Jeon YS, Rhee YG. Treatment of acute shoulder infection: can osseous lesion be a rudder in guideline for determining the method of débridement? J Shoulder Elbow Surg. 2019;28(12):2317-25.

39. Newman JH. Review of septic arthritis throughout the antibiotic era. Ann Rheum Dis. 1976;35(3):198-205.

40. Berthoud O, Coiffier G, Albert JD, GougeonJolivet A, Goussault C, Bendavid C et al. Performance of a new rapid diagnostic test the lactate/glucose ratio of synovial fluid for the diagnosis of septic arthritis. Joint Bone Spine. 2020;87(4):343-50.

41.Johns BP, Loewenthal MR, Dewar DC. Open Compared with Arthroscopic Treatment of Acute Septic Arthritis of the Native Knee. J Bone Joint Surg Am. 2017;99(6):499-505.

42. Stutz G, Kuster MS, Kleinstück $F$, Gächter A. Arthroscopic management of septic arthritis: stages of infection and results. Knee Surg Sports Traumatol Arthrosc. 2000;8(5):270-74.

43. Rühmann $O$, Schmolke $S$, Bohnsack $M$, Flamme C, Wirth CJ. Shoulder arthrodesis: indications, technique, results, and complications. J Shoulder Elbow Surg. 2005;14(1):38-50.

44. Joo YB, Lee WY, Shin HD, Kim KC, Kim YK. Risk factors for failure of eradicating infection in a single arthroscopic surgical procedure for septic arthritis of the adult native shoulder with a focus on the volume of irrigation. J Shoulder Elbow Surg. 2020;29(3):497-501.

45. Bovonratwet P, Fu MC, Pathak N, Ondeck NT, Bohl DD, Nho SJ, Grauer JN. Surgical treatment of septic shoulders: a comparison between arthrotomy and arthroscopy. Arthroscopy. 2019;35(7):1984-1991.

46. Böhler C, Pock A, Waldstein W, Staats K, Puchner SE, Holinka J et al. Surgical treatment of shoulder infections: a comparison between arthroscopy and arthrotomy. J Shoulder Elbow Surg. 2017;26(11):1915-21. 


\section{CONFLICTS OF INTERESTS}

The authors declare no conflicts of interests.

\section{CORRESPONDING AUTHOR}

\section{Roberto Barreto Maia}

Hospital Santa Izabel

Praça Conselheiro Almeida Couto, 500 - Nazaré

40050-410 Salvador, BA, Brazil

e-mail: rbmaia77@gmail.com

Received 23/01/2021

Accepted 04/02/2021 